\title{
PENGARUH HEALTH COACHING BERBASIS TEORI HEALTH BELIEF MODEL TERHADAP TEKANAN DARAH PADA LANSIA DENGAN HIPERTENSI
}

\author{
Apriyani Puji Hastuti ${ }^{1}$, Hanim Mufarokhah ${ }^{2}$ \\ Poltekkes RS dr. Soepraoen Malang \\ Email: nns.apriyani@gmail.com , $\underline{\text { Hanim.mufarokhah@gmail.com }}$
}

\begin{abstract}
Introduction: Most people with hypertension assume that consumption drugs can control their blood pressure. In fact, lifestyle factor such as physical activity contribute to the burden of account for substantial morbidity, mortality, and rising in hypertension, highlighly the much for prevention afford to curb public health epidemic. Health coaching was one way for the nurse to improve motivation and patient's beliefs concerning their disease so that they would show good compliance behavior. Objective of this study was to analyze the effect of health coaching toward physical activity. Methods: This study used quasi experiment design with prepost test control group design. Sample collection technique was by purposive sampling. The amount of sample was 26 person for each group. There were two variables, the dependent and independent variables, the dependent variable was physical activity and the independent variable was health coaching. The location in the work Pandanwangi health public care and the time was April- Juli 2019. Statistical data test used were Mann Whitney and Sign Rank Test Wilcoxon. Result: Health coaching has effect to systolic blood pressure only. Difference test in treatment group using Wilcoxon obtain p value 0,000, while differece test with Mann Whitney obtain p value 0,000. Discussion: There is blood pressure differences between treatment and control group. It is expected hypertension patients should be always doing use hypertension management to control blood pressure.
\end{abstract}

Keywords: health coaching, hypertension, blood pressure

\section{LATAR BELAKANG}

Ketidaktahuan pasien hipertensi akan bahaya dan komplikasi hipertensi membuat pasien hipertensi derajat I meningkat menjadi hipertensi derajat II. Pasien hipertensi beranggapan bahwa dengan konsumsi obat saja sudah cukup mengontrol tekanan darahnya. Pada pasien hipertensi derajat I yang mampu mengatur perilakunya seperti mengontrol pola makan dan berolah raga, kecil kemungkinan untuk meningkat derajatnya menjadi hipertensi derajat II. Pada saat seseorang didiagnosis hipertensi, tenaga kesehatan akan meminta pasien untuk mengatur gaya hidupnya. Mulai dari pengaturan pola makan, asupan garam, pembatasan konsumsi kopi dan alkohol, peningkatan aktifitas fisik atau olahraga, menghentikan kebiasaan 
merokok, mengatur stress atau kondisi marah, dan mengikuti program pengobatan. Penyuluhan yang sudah diberikan selama ini oleh petugas kesehatan tidak memberikan pengaruh yang nampak dalam perubahan perilaku compliance penderita hipertensi karena tidak adanya feedback atau kesempatan untuk penderita hipertensi mengutarakan informasi apa yang sebenarnya mereka butuhkan tentang kesehatannya. Perubahan perilaku dengan strategi paksaan juga tidak dapat diterapkan pada masyarakat desa. Strategi lain yang dapat dilakukan dengan kekuatan pengaturan atau hukum, namun selama ini belum pernah ada hukum dalam masyarakat baik tertulis maupun tidak tertulis yang fokus pada masalah kesehatan. Karenanya pemberian informasi dan pendampingan dalam perubahan perilaku compliance dipilih sebagai intervensi untuk masyarakat desa.

Pada kenyataannya tidak semua penderita hipertensi dapat mengatur gaya hidupnya. Terkait dengan mematuhi saran petugas kesehatan, pasien hipertensi akan melakukan penilaian terhadap kondisi kesehatannya. Perbedaan akan penghayatan penyakit yang diderita oleh pasien hipertensi, berkaitan dengan penilaian pasien akan ancaman dari suatu penyakit. Berdasarkan Health Belief Model, kemungkinan seseorang akan melakukan tindakan pencegahan tergantung pada hasil dari keyakinan atau penilaian kesehatannya (Priyoto, 2014). Pasien akan mengambil tindakan untuk mencegah, mengurangi, atau mengontrol kondisi gangguan kesehatan didasari dari tujuh komponen health belief model yang diharapkan. Perilaku compliance dapat diartikan sebagai usaha yang dilakukan oleh pasien dalam bentuk, mengikuti aturan medis, mengikuti diet atau perubahan pola hidup yang sesuai dengan nasehat medis (Sarafino, 2011).

Dari hasil studi pendahuluan yang dilaksanakan di Wilayah Kerja Puskesmas Pandanwangi Malang menunjukan bahwa jumlah kunjungan penderita hipertensi sebanyak 1060 kali. Fakta Riskesdas, 2013 menyatakan bahwa penduduk usia >10 tahun merokok setiap hari sebanyak 23,7\%. Jumlah makanan asin yang dikonsumsi dan asupan garam masih cukup tinggi yaitu sebanyak $15 \mathrm{gr} / \mathrm{hari}$ dan melebihi yang batas anjuran yaitu $6 \mathrm{gr} / \mathrm{hr}$, dan sebanyak 24,5\% masyarakat diatas usia 10 tahun mengkonsumsi makanan asin setiap hari. Sebanyak 93,6\% masyarakat kurang mengkonsumsi buah dan sayuran (Kemenkes, 2013). Hasil Riskesdas tahun 2013 menyatakan bahwa sebanyak 26,1\% penduduk Indonesia tergolong kurang dalam melakukan aktivitas fisik. Terdapat 22 propinsi di Indonesia dan termasuk Jawa Timur yang memiliki penduduk dengan kategori aktifitas fisik kurang yaitu sebanyak 33,9\% (Kemenkes, 2013). Serta data dari NHANES 2007-2010 terdapat 47,5\% penderita hipertensi yang tidak mengontrol tekanan darahnya (American Heart Association, 2013). Pasien hipertensi yang memiliki perilaku compliance yang buruk dapat meningkatkan derajat hipertensinya dan mengarah pada komplikasi meliputi infark miokard, stroke, gagal ginjal, dan kematian jika tidak dideteksi secara dini dan ditangani dengan tepat (James, et al., 2014).

Hasil studi tentang penggunaan tehnik health coaching pada beberapa penelitian sebelumnya beragam diantaranya: memberikan pengalaman yang positif bagi partisipan, memberikan hasil yang maksimal yang dirasakan dikemukakan oleh Priyoto (2014) yaitu di dalam teori health belief model mengungkapkan bahwa perilaku sehat individu dipengaruhi oleh konstruksi teoritis tentang hal yang dipercaya oleh individu untuk berperilaku dalam peningkatan kesehatan. Keyakinan tersebut yaitu Persepsi kerentanan responsif tentang kemungkinan terserang penyakit atau kondisi sakit (Perceived susceptibility), Perasaan tentang keseriusan tertular penyakit atau tidak diobati termasuk evaluasi konsekuensi medis dan klinis (misalnya, kematian, kecacatan, dan rasa sakit) dan kemungkinan konsekuensi sosial (seperti efek dari kondisi pada pekerjaan, kehidupan keluarga, dan hubungan sosial) (Perceived Severity), keyakinan orang tersebut mengenai manfaat yang dirasakan dari berbagai tindakan yang tersedia untuk mengurangi ancaman penyakit (Perceived Benefits), individu menimbang manfaat yang diharapkan dari tindakan tersebut dengan hambatan yang dirasakan (Perceived 
Barriers), isyarat yang dapat memicu tindakan kesehatan yang direkomendasikan (Cues to action), keyakinan bahwa seseorang dapat berhasil mengeksekusi perilaku yang diperlukan untuk menghasilkan hasil (Self-efficacy). Dengan health coaching yang berupa pembinaan kesehatan yang berupa konsultasi berbasis evidence based, intervensi klinis dan strategi untuk secara aktif dan aman melibatkan klien / pasien dalam perubahan perilaku kesehatan dapat mengubah perilaku sehat klien dengan berdasarkan pada Health Belief Model.Komponen HBM ini sangat cocok untuk mengatasi masalah perilaku yang memiliki konsekuensi terhadap masalah kesehatan (misal: konsumsi makanan yang tidak sehat, kurangnya aktivitas fisik). HBM telah banyak diadaptasi dan berhasil diterapkan dalam desain intervensi kesehatan (Orji, Mandryk, \& Vassileva, 2012).

\section{METODE}

\section{HASIL DAN DISKUSI}

Puskesmas Pandanwangi Kota Malang merupakan Faskes Tingkat Pertama BPJS Kesehatan di Malang dengan tipe Non Rawat Inap yang terletak di Jalan Laksamana Adi Sucipto No. 315, Pandanwangi, Blimbing, Kota Malang, Jawa Timur, dengan wilayah kerja Puskesmas Pandanwangi meliputi : Kelurahan Pandanwangi, Purwodadi, Blimbing, dan Purwantoro. Fasilitas pelayanan kesehatan yang terdapat di Puskesmas Pandanwangi meliputi: Balai Pengobatan, gigi, KIA (Kesehatan Ibu dan Anak), Apotek, Laboratorium sederhana, dan UGD (Unit Gawat Darurat).

Tatalaksana pasien hipertensi di Puskesmas Pandanwangi Kota Malang sesuai standar operasional puskesmas bulan Desember 2018 yaitu saat penemuan pasien baru dengan tekanan darah mencapai 140/90 $\mathrm{mmHg}$ pasien diberikan edukasi dan dianjurkan untuk melakukan perubahan gaya hidup baik pengaturan pola makan, peningkatan aktivitas fisik, penurunan berat badan, membatasi bahkan berhenti merokok, dan manajemen stress selama satu bulan. Selanjutnya pasien diminta untuk datang kontrol kembali ke puskesmas, bila didapatkan tekanan darah pada nilai tetap atau meningkat maka dilanjutkan pada program pengobatan. Bila tekanan darah turun maka pengaturan gaya hidup tetap dilanjutkan di rumah dan diminta untuk kembali pada bulan berikutnya. Hasil analisis data umum yang peneliti dapatkan pada penelitian ini berdasarkan jenis kelamin, umur, pendidikan, pekerjaan, riwayat penyakit hipertensi, dan riwayat penyakit ginjal adalah sebagai berikut:

Tabel 1 Hasil analisis data umum

\begin{tabular}{lllllll}
\hline \multirow{2}{*}{$\begin{array}{l}\text { Karakteristik } \\
\text { Responden }\end{array}$} & \multicolumn{2}{l}{$\begin{array}{l}\text { Kelompok } \\
\text { Perlakuan }\end{array}$} & \multicolumn{2}{l}{ Kelompok Kontrol } & Total & \\
\cline { 2 - 7 } & $\mathbf{f}(\mathbf{o r g})$ & $\mathbf{\%}$ & $\mathbf{f}(\mathbf{o r g})$ & $\mathbf{\%}$ & $\mathbf{n}$ & $\boldsymbol{\%}$ \\
\hline Jenis Kelamin & & & & & & \\
\hline Laki-laki & 8 & $30,8 \%$ & 6 & $23,1 \%$ & 14 & $26,9 \%$ \\
\hline Perempuan & 18 & $69,2 \%$ & 20 & $76,9 \%$ & 38 & $73,1 \%$ \\
\hline Umur & & & & & & \\
\hline $36-45$ tahun & 4 & $15,4 \%$ & 0 & $0 \%$ & 4 & $7,7 \%$ \\
\hline $46-55$ tahun & 22 & $84,6 \%$ & 26 & $100 \%$ & 48 & $92,3 \%$ \\
\hline Pendidikan & & & & & & \\
\hline
\end{tabular}




\begin{tabular}{lllllll}
\hline SD & 6 & $23 \%$ & 12 & $46,1 \%$ & 18 & $34,6 \%$ \\
\hline SMP & 10 & $38,5 \%$ & 6 & $23,1 \%$ & 16 & $30,8 \%$ \\
\hline SMA & 10 & $38,5 \%$ & 6 & $23,1 \%$ & 16 & $30,8 \%$ \\
\hline Perguruan Tinggi & 0 & $0 \%$ & 2 & $7,7 \%$ & 2 & $3,8 \%$ \\
\hline Pekerjaan & & & & & & \\
\hline IRT & 12 & $46,2 \%$ & 16 & $61,5 \%$ & 28 & $53,8 \%$ \\
\hline Pegawai Swasta & 12 & $46,2 \%$ & 4 & $15,4 \%$ & 16 & $30,8 \%$ \\
\hline PNS & 0 & $0 \%$ & 4 & $15,4 \%$ & 4 & $7,7 \%$ \\
\hline Wiraswasta & 2 & $7,6 \%$ & 2 & $7,7 \%$ & 4 & $7,7 \%$ \\
\hline Riwayat Penyakit & & & & & & \\
Hipertensi & 10 & $38,5 \%$ & 10 & $38,5 \%$ & 20 & $38,5 \%$ \\
\hline Ya & 16 & $61,5 \%$ & 16 & $61,5 \%$ & 32 & $61,5 \%$ \\
\hline Tidak & & & & & & \\
\hline $\begin{array}{l}\text { Riwayat Penyakit } \\
\text { Ginjal }\end{array}$ & 0 & $0 \%$ & 0 & $0 \%$ & 0 & $0 \%$ \\
\hline Ya & 26 & $100 \%$ & 26 & $100 \%$ & 52 & 100 \\
\hline Tidak & & & & & & \\
\hline Subr: Data Prmer & & & & & & \\
\hline
\end{tabular}

(Sumber: Data Primer, 2019)

Berdasarkan tabel 1 terlihat bahwa pada kelompok perlakuan pada penelitian ini sebagian besar berjenis kelamin perempuan yaitu sejumlah 18 responden $(69,2 \%)$ dengan usia hampir seluruhnya adalah $46-55$ tahun $(84,6 \%)$ dan tingkat pendidikan hampir setengahnya yaitu SMP dan SMA dengan jumlah yang sama masing-masing 10 responden (38,5\%), jenis pekerjaan hampir setengahnya yaitu ibu rumah tangga dan pegawai swasta dengan jumlah yang sama masing-masing 12 responden $(46,2 \%)$, serta sebagian besar mempunyai riwayat penyakit hipertensi $(61,5 \%)$. Sedangkan pada kelompok kontrol hampir seluruhnya responden berjenis kelamin perempuan sebanyak 20 responden (76,9\%), dengan rentang usia seluruhnya 46-55 tahun (100\%), tingkat pendidikan hampir setengahnya adalah SD yaitu 12 responden $(46,1 \%)$, jenis pekerjaan sebagian besar sebagai ibu rumah tangga sebanyak 816 responden $(61,5 \%)$, serta sebagian besar mempunyai riwayat penyakit hipertensi $(61,5 \%)$

Tabel 2 Hasil analisis tekanan darah sistol dan diastol pre test post test kelompok perlakuan dan kontrol

KELOMPOK PERLAKUAN KELOMPOK KONTROL

\begin{tabular}{llll}
\hline Mean \pm SD & Median & Mean \pm SD & Median
\end{tabular}

\begin{tabular}{lcccl}
\hline Pre & & & & \\
Sistol & $161.54 \pm 17.82$ & 160 & $161.54 \pm 17.82$ & 160 \\
Diastol & $80 \pm 0$ & 80 & $84.62 \pm 5.084$ & 80 \\
\hline Post test & & & & \\
Sistol & $140 \pm 6.928$ & 140 & $152.31 \pm 9.081$ & 160 \\
\hline
\end{tabular}




\begin{tabular}{lllll}
\hline Diastol & $80.77 \pm 2.717$ & 80 & $84.62 \pm 5.084$ & 80 \\
& & & \\
\hline Sistol & $Z=-4.053$ & $Z=-3.101 \alpha=0.02$ & $\alpha=0.000$ \\
& $\alpha=0.000$ & & $\alpha=-3.464$ & $\alpha=0.013$ \\
\hline Diastol & $Z=1$ & $\alpha=0.01$ & \\
& $\alpha=0.000$ & & \\
\hline
\end{tabular}

Berdasarkan tabel di atas didapatkan pada pre test kelompok perlakuan dan kelompok kontrol memiliki nilai mean yang sama yaitu nilai tekanan darah sistol reratanya dengan sistol $160 \mathrm{mmHg}$. Dari uji Mann Whitney untuk data tekanan darah sistol pre test kelompok perlakuan dan kontrol didapatkan nilai $\mathrm{p}$ value sebesar 0.000 artinya $\mathrm{H} 0$ ditolak atau hipotesis penelitian di terima yang menyatakan ada beda antara kelompok kontrol dan perlakuan terhadap pengukuran tekanan darah sebelum intervensi health coaching dengan pendekatan Health Belief Model (HBM).

Nilai tekanan darah post test pada kelompok perlakuan didapatkan tekanan darah diastol reratanya adalah $80.77 \pm 2.717$. Dari uji Mann Whitney untuk data tekanan darah diastol post test kelompok perlakuan dan kontrol didapatkan nilai $\mathrm{p}$ value sebesar 1 yang artinya $\mathrm{H} 0$ di terima dengan asumsi bahwa hipotesis penelitian di tolak yang menyatakan tidak ada beda antara kelompok kontrol dan perlakuan terhadap pengukuran tekanan darah sistol setelah intervensi health coaching dengan pendekatan Health Belief Model (HBM).

Nilai tekanan darah sistol responden sebelum dilakukan pada kelompok intervensi menunjukkan mean yang sama, dan hasil uji Mann Whitney menunjukkan tidak ada perbedaan antara kelompok perlakuan dan kontrol. Tekanan darah diawali pada rentang yang sama antara kedua kelompok yaitu 140-169/ 90-99 mmHg berada pada klasifikasi hipertensi derajat I menurut JNC 8 dan Perhimpunan Dokter Spesialis Kardiovaskuler Indonesia (2015). Fakta ini juga menggambarkan health belief atau persepsi kesehatan responden pada kondisi yang sama. Hasil identifikasi health belief dari responden bahwa komponen kerentanan yang dirasakan (Perceived Susceptibility) dan komponen keparahan yang dirasakan (Perceived Severity) terhadap hipertensi menunjukkan sebagian besar jawaban responden menganggap hipertensi adalah penyakit yang dapat sembuh dengan minum obat saja dan tidak menjadi hal yang perlu dikawatirkan selama tidak ada gejala yang dirasakan.

Menurut Brookes (2007) yang perlu dilakukan oleh penderita hipertensi derajat I yaitu mengadakan perubahan pola hidup sebagai pilihan pertama untuk penanganannya. Selain itu juga dibutuhkan pengobatan untuk mengendalikan tekanan darah bila mulai tidak terkontrol. Pengaturan gaya hidup bisa dilakukan selama 1 bulan sebelum pengobatan (Direktorat Jenderal PP \& PL, 2006).

Hal ini sejalan dengan pemberian intervensi health coaching dengan pendekatan Health Belief Model yang bertujuan untuk memotivasi penderita hipertensi dalam merubah perilaku compliance berupa pengaturan pola makan dan aktivitas fisik. Perilaku compliance yang dikontrol mampu menurunkan tekanan darah atau mempertahankan dalam rentang normal. Rentang nilai tekanan darah yang sama pada hasil penelitian juga menunjukkan kesamaan jenis kelamin responden yang sebagian besar adalah perempuan dengan usia pasca menopause. Seperti yang disebutkan Udjianti (2011) bahwa beberapa faktor pendukung terjadinya hipertensi adalah jenis kelamin perempuan dengan usia pasca menopause. Sejalan pula dengan penelitian Martiningsih (2011) yang menganalisis faktor yang berhubungan dengan terjadinya hipertensi, ditemukan lebih dari setengah responden penelitian adalah perempuan dengan usia sebagain besar diatas 46 tahun yang merupakan usia menopause. Dilaporkan pula oleh Thomas (2007) bahwa persentase kejadian hipertensi meningkat pada wanita diatas 49 tahun.

Semakin bertambah usia individu terutama di usia > 45 tahun maka semakin lama dinding pembuluh darah akan menyempit dan kaku yang dikarenakan adanya penumpukan zat 
kolagen pada miovaskular. Kekakuan dinding pembuluh darah ini menyebabkan peningkatan tekanan dari aliran darah di dalam arteriol. Meningkatnya tekanan aliran darah ke dinding arteri menyebabkan kerusakan, menghasilkan pembentukan plak aterosklerotik. Pada penambahan umur sampai dekade ketujuh tejadi peningkatan tekanan darah sistolik yang dikarenakan berkurangnya kelenturan pembuluh darah besar. Serta pada dekade kelima dan keenam terjadi peningkatan tekanan darah diastolik, kemudian akan menetap atau cenderung menurun. Terjadi perubahan fisiologis dengan adanya peningkatan resistensi perifer dan aktivitas katekolamin menyebabkan pengaturan tekanan darah menjadi lebih sensitif dengan menstimulasi refleks baroreseptor serta berkurangnya peran ginjal mengakibatkan aliran darah dalam ginjal menurun sehingga laju filtrasi glomerulus juga menurun. Peningkatan volume plasma terjadi akibat dari retensi garam dan air dari ketidakadekuatan ginjal mengeliminasi beban graam (Sherwood, 2011). Selain itu, pada filtrasi ginjal yang menurun, hormon renin akan dikeluarkan oleh sel aparatus ginjal sehingga mengaktifkan angiotensinogen di plasma menjadi angiotensin I yang melewati sirkulasi pulmonal dan berubah menjadi vasokonstriktor yang kuat yaitu angiotensinogen II oleh Angiotensin Converting enzyme (ACE). Disamping itu angiotensin II merangsang aldosteron di dalam korteks adrenal mengakibatkan retensi natrium sehingga osmolalitas pada plasma meningkat dan diimbangi absorbsi air meningkat juga. Keadaan tersebuta akan mengakibatkan peningkatan darah arteri yang disebabkan curah jantung yang meningkat (Guyton, 2007).

Pria dan wanita memiliki prevalensi yang sama untuk terjadi hipertensi, namun setelah pubertas wanita biasanya mempunyai tekanan darah lebih rendah daripada laki-laki pada usia yang sama. Hal ini terjadi akibat perbedaan hormonal. Wanita lebih cenderung mempunyai tekanan darah lebih tinggi dari sebelumnya setelah menopause. Hal ini dikarenakan pada wanita terdapat hormon estrogen yang menstimulasi peningkatan kadar High Density Lipoprotein (HDL) sehingga proses aterosklerosis dapat dicegah. Seiring penambahan usia menuju ke premenopause, maka secara alami hormon estrogen mengalami penurunan yaitu pada usia 4555 tahun. Wanita dengan usia diatas 50 tahun yang telah mengalami menopause memiliki beberapa perubahan fisik, hormon, dan mental. Disertai beberapa keluhan seperti kelelahan, gugup, sakit kepala, insomnia, depresi, iritabilitas, nyeri sendi dan otot, pusing, dan jantung berdebar. Emosi yang labil juga dapat menimbulkan gangguan tidur. Akumulasi keluhan di atas serta kondisi pembuluh darah yang sudah mulai kaku mengakibatkan peningkatan tekanan darah (Guyton, 2007).

Intervensi yang diberikan selama proses penelitian berupa health coaching dengan pendekatan Health Belief Model mampu memberikan pemahaman tentang nutrisi untuk penderita hipertensi. Peningkatan pengetahuan tentang nutrisi mendasari perubahan perilaku responden dalam pengaturan pola makan. Isyarat untuk bertindak (Cues to Action) yang mempengaruhi perubahan perilaku compliance bisa berasal dari petugas kesehatan.

Pembatasan garam membantu menurunkan antidiuretik hormon sehingga tidak terjadi reabsorbsi air berlebih di tubulus ginjal, dan mampu mengekskresikan air melalui ginjal dengan baik. Dengan demikian tidak terjadi peningkatan volume darah, aliran balik vena tidak mengalami peningkatan yang selanjutnya mempengaruhi tekanan pengisian jantung dan kekuatan kontraksi jantung. Antideuretik hormon yang tidak meningkat juga tidak menimbulkan kontraksi pembuluh darah dan tidak menyebabkan peningkatkan tahanan pembuluh darah, sehingga tekanan darah tidak meningkat (Guyton A, 2007).

Stres dapat mengakibatkan kenaikan tekanan darah, hal ini terjadi karena stimulasi sistem saraf simpatis (saraf yang bekerja pada saat kita beraktivitas) secara intermitten (tidak menentu) sehingga meningkatkan cardiac output dan vasokonstriksi arteriol. Berbagai macam stresor yang dapat mengakibatkan stres diantaranya marah, takut, sangat gembira, gangguan psikis lainnya, nyeri, pembedahan, terapi medis, obat-obatan, penyakit, trauma, infeksi, usia tua, bahkan obesitas. Menurut Muhammadun (2010) stres mengakibatkan pelepasan epinefrin (adrenalin) dan hormon- 
hormon lain yang membuat pembuluh darah menyempit atau menyebabkan penumpukan lebih banyak natrium dan air sehingga mengakibatkan peningkatan kecepatan serta kekuatan denyut jantung yang akhirnya mengakibatkan peningkatan tekanan darah. Hal ini bisa saja terjadi karena sebagain besar pekerjaan responden adalah ibu rumah tangga yang setiap hari melakukan rutinitas yang sama, mengerjakan urusan yang sama, dan fokus pada keluarga serta masalah keluarga yang ada, tanpa ada selingan hiburan dengan beban kerja selama 24 jam. Saat masalah keluarga datang akan menjadi fokus pemikiran bagi responden. Hal ini yang dapat menjadi stresor dan menimbulkan stres bagi responden yang berakibat dapat meningkatkan tekanan darah responden.

Sesuai yang disebutkan oleh Priyoto (2014) bahwa dalam perubahan perilaku membutuhkan kesiapan dari individu itu sendiri, yang dijabarkan melalui proses Transtheoretical Model bahwa tahap perubahan perilaku dimulai dari precontemplation (niat untuk bertindak dimasa depan), contemplation (penilaian kembali pada diri sendiri), preparation (self liberation), action (tindakan), maintenance (pemeliharaan), relaps (kekambuhan). Dalam proses penelitian ini telah terjadi beberapa tahap mulai dari adanya niat, penilaian diri sendiri, dan self liberation yang diperoleh dari intervensi health coaching dengan pendekatan Health Belief Model. Karena proses penelitian yang singkat dan stimulus sudah diberikan responden belum sampai pada tahap pemeliharaan. Seseorang dapat baik untuk satu jenis perilaku compliance tapi tidak untuk perilaku compliance yang lain. Untuk mampu mencapai kondisi baik untuk semua perilaku compliance dibutuhkan waktu yang lama.

\section{KESIMPULAN}

Ada pengaruh pemberian health coaching dengan pendekatan Health Belief Model dengan tekanan darah sistol pada lansia yang mengalami hipertensi dengan $\alpha=0.000$ dan tidak ada pengaruh pemberian health coaching berbasis Teori Health Belief Model terhadap tekanan darah diastol pada lansia yang mengalami hipertensi dengan $\alpha=1.000$.

\section{SARAN}

1. Penderita hipertensi diharapkan rutin untuk memeriksakan tekanan darah.

2. Hasil penelitian ini dapat digunakan perawat untuk modifikasi intervensi keperawatan dengan pemanfaatan metode diary guna meningkatkan perilaku compliance penderita hipertensi. Terutama dokumentasi pengaturan pola makan karena keragaman makanan yang biasa dikonsumsi oleh penderita hipertensi.

3. Perawat dapat meningkatkan self efficacy penderita hipertensi melalui program puskesmas yang melibatkan penderita hipertensi seperti posyandu lansia.

4. Dapat digunakan puskesmas untuk dasar pengembangan program dengan membentuk group support peduli penderita hipertensi dan turut melibatkan kader didalamnya.

5. Pada penelitian lanjutan dapat melakukan health coaching lebih terstruktur, rutin, dan terjadwal pada penderita hipertensi agar hasil lebih optimal.

\section{REFERENSI}

1. Abdi, Z. (2015). Analisis Pengaruh Perilaku Pencegahan Hipertensi Berdasarkan Konsep Health Belief Model dan Dukungan Sosial pada Masyarakat Desa Baruh jaya Propinsi Kalimantan Selatan. Surabaya: Fakultas Kesehatan Masyarakat Universitas Airlangga.

2. American Heart Association. (2013). High Blood Pressure. United States: American Heart Association. 
3. Azam, M. (2005). Prevalensi Hipertensi berdasarkan Riwayat Hipertensi dalam Keluarga. Jakarta: Erlangga.

4. Conner, M. (2010). Cognitive Determinants of Health Behavior Handbook of Behavioral Medicine Methods and Applications.

5. Dahlan, M. (2013). Besar Sampel dan Cara Pengambilan Sampel dalam Penelitian Kedokteran dan Kesehatan . Jakarta: Salemba Medika.

6. Departement of Health and Human Service, U. (2003). Your Guide to Lowering Blood Pressure. NIH Publication.'

7. Direktorat Jenderal PP \& PL, Departemen Kesehatan RI. (2006). Pedoman Teknis Penemuan dan Tatalaksana Penyakit Hipertensi. Jakarta: Departemen Kesehatan RI.

8. Guyton, A. (2007). Buku Ajar Fisiologi Kedokeran. Jakarta : EGC. Harrison. (2000). Prinsip-prinsip Ilmu Penyakit Dalam. Jakarta : EGC.

9. Kementerian Kesehatan Republlik Indonesia. (2013). Riset Kesehatan Dasar. Jakarta: Badan Penelitian dan Pengembangan Kesehatan Kementrian Kesehatan RI.

10. Kurniawan. (2002). Hipertensi dan Penyebabnya. Jakarta: Rineka Cipta.

11. Lawrence, J. (2009). Dietary Approaches to Lower Blood Pressure. The Journal of Clinical Hypertension, 11 (7)

12. Li, C., Unger, J., Schuster, D., Rohrbach, L., Howard-Pitney, B., \& Norman, G. (2003). Youths Exposure to Environmental Tobacco Smoke (ETS) Associations with Health Belief and Social Pressure. Addictive Behaviors, 28, 39-53.Mentri Kesehatan Republik Indonesia. (2014). Peraturan Menteri Kesehatan Republik Indonesia Nomor 41 tentang Pedoman Gizi Seimbang. Jakarta.

13. Muhammadun, A. (2010). Hidup Bersama Hipertensi. Jogjakarta: In-Books.

14. Ngo, V., Hammer, H., \& Bodenheimer, T. (2010). Innovation and Improvement: Internal Examination Health Coaching in The Teamlet Model: A Case Study. J Gen Intern Med, 25 (12), 1375-8.

15. NHS. (2014). NHS Improving Quality. Retrieved from Long Term Conditions Programmes: http://www.nhsiq.nhs.uk

16. Nursalam. (2014). Metodologi Penelitian Ilmu Keperawatan. Jakarta: Salemba Medika.

17. Perhimpunan Dokter Spesialis Kardiovaskuler Indonesia. (2015). Pedoman Tatalaksana Hipertensi pad Penyakit Kardiovaskuler. Jakarta.

18. Sani, A. (2008). Hypertension, Current Perspective. Jakarta: Medya Crea. Sarafino, E. (2011). Health Psychology Biopsychosocial Interactions. New York:Johnwilley and Sons Ltd.

19. Schneider, J., Hashizume, J., Heak, S., Maetani, L., Ozaki, R., \& Watanabe, D. (2011). Identifying Challenges, Goals and Strategies for Success for People with iabetes through Life Coaching. Honolulu, HI, USA: University of Hawai at Manoa.

20. Sumarman. (2010). Penderita Hiprtensi Primr:Pengetahuan tentang Diet Rendah Garam, Kepatuhan dan Kendalanya. Surakarta: Tesis, Program Pascasarjana, Universitas Sebelas Maret .

21. Udjianti, W. J. (2011). Keperawatan Kardiovaskuler. Jakarta: Salemba Medika.

22. Viney, R., \& Paice, E. (2010). The First Five Hundred: A Report on London

23. WebMD. (2013). The Essensial Guide to Health Coaching. WebMD Health Service.

24. Wong-Rieger, D. (2011). Health Coaching for Chronic Conditions Engaging and Supporting Patients to Self Manage. Canada: Institute for Optimizing health Outcomes. 